\title{
1 Aboveground biomass increments over 26 years (1993-2019) 2 in an old-growth cool-temperate forest in northern Japan
}

3 Mahoko Noguchi $^{1 *}$, Kazuhiko Hoshizaki ${ }^{2}$, Michinari Matsushita $^{3}$,

4 Daiki Sugiura $^{2}$, Tsutomu Yagihashi ${ }^{4}$, Tomoyuki Saitoh ${ }^{1}$, Tomohiro Itabashi ${ }^{2}$,

5 Ohta Kazuhide ${ }^{2}$, Mitsue Shibata ${ }^{4}$, Daisuke Hoshino ${ }^{4}$, Takashi Masaki ${ }^{4}$,

6 Katsuhiro Osumi ${ }^{5}$, Kazunori Takahashi ${ }^{6}$, Wajirou Suzuki ${ }^{7}$

${ }^{1}$ Tohoku Research Center, Forestry and Forest Products Research Institute, Morioka, 020-0123, Japan

$8{ }^{2}$ Department of Biological Environment, Akita Prefectural University, Akita, 010-0195, Japan

$9{ }^{3}$ Forest Tree Breeding Center, Forestry and Forest Products Research Institute, Hitachi, 319-1301, Japan

$10 \quad{ }^{4}$ Forestry and Forest Products Research Institute, Tsukuba, 305-8687, Japan

${ }^{5}$ Field Science Center, Faculty of Agriculture, Tottori University (retired), Tottori, 680-8553, Japan

${ }^{6}$ Kansai Research Center, Forestry and Forest Products Research Institute, Kyoto, 612-0855, Japan

${ }^{7}$ Forestry and Forest Products Research Institute (retired), Tsukuba, 305-8687, Japan

* Corresponding author. E-mail: mahoko@ffpri.affrc.go.jp

Abstract

Assessing long-term changes in biomass of old-growth forests is critical in evaluating forest ecosystem functions under a changing climate. Long-term biomass changes are the result of accumulated short-term changes, which can be affected by endogenous processes such as gap filling in small-scale canopy openings. Here, we used 26 years (1993-2019) of repeated tree census data in an old-growth, cool-temperate, deciduous mixed forest that contains three topographic units (riparian, denuded slope, and terrace) in northern Japan to document decadal changes in aboveground biomass (AGB) and their processes in relation to endogenous processes and climatic factors. AGB increased steadily over the 26 years in all topographic units, but different tree species contributed to the increase among the topographic units. AGB gain within each topographic unit exceeded AGB loss via tree mortality in most of the measurement periods despite substantial temporal variation in AGB loss. At the local scale, variations in AGB gain were partially explained by compensating growth of trees around canopy gaps. Climate affected the local-scale AGB gain: the gain was larger in the measurement periods with higher mean temperature during the current summer but smaller in those with higher mean temperature during the previous autumn, synchronously in all topographic units. The decadal climate trends of warming are likely to have contributed to the steady increase in AGB in this old-growth forest. 
Key words: forest biomass $\cdot$ long-term data $\cdot$ Kanumazawa Riparian Research Forest $•$ temperature

\section{Introduction}

Old-growth forests are widely recognized to play an important role in the carbon cycle (Luyssaert et al. 2008). It has been commonly accepted that old-growth forests are carbon neutral (Odum 1969) and their aboveground biomass (AGB) is at 'steady state', with equal gross primary production and respiration (Bormann and Likens 1979). However, recent studies indicate that they grow continuously (Foster et al. 2014) and work as carbon sinks with increasing biomass over centuries (Luyssaert et al. 2008). As biomass growth of oldgrowth forests is more susceptible to climate change than that in young forests (Chen et al. 2016), assessing long-term changes in biomass of old-growth forests is critical in evaluating the effects of climate change on forest ecosystem functions (McDowell et al. 2020).

Long-term changes in biomass result from the accumulation of short-term changes in the form of gain due to tree growth and loss due to mortality (Hoshizaki et al. 2004). Therefore, to understand how climate affects changes in AGB, the effects of climatic factors on each component need to be taken into account (Chen and Luo 2015; Peña et al. 2018). In addition, endogenous processes such as gap filling in small-scale canopy openings can drive biomass change (Phillips et al. 2009; McDowell et al. 2020): at the local scale, gap formation may cause first a decrease and then an increase in AGB caused by growth promotion of trees around the gap. Repeatedly measured tree census data with tree location can be useful in revealing these processes.

Environmental factors such as topographic position affect both forest biomass (Kubota et al. 2004; Valencia et al. 2009) and tree species composition (Chen and Luo 2015;

Kuuluvainen et al. 2017; Ohmann and Spies 1998). For instance, on northern Honshu, Japan, Fagus crenata often dominates forest stands on hillslopes, whereas more tree species occur in riparian areas (Suzuki et al. 2002). Tree species in riparian forests have diverse life history traits (e.g., both shorter and longer lifespans, heavy sprouting; Nakamura and Inahara 2007; Sakio 2020). Therefore, hillslope and riparian stands are expected to differ in the dynamics (i.e., growth and mortality) and, consequently, the pattern of biomass changes in component species. In addition, a recent analysis of long-term tree census data in northern Japan has revealed different responses among species to changing climate and consequent changes in 
stand structure and species composition (Hiura et al. 2019). Thus, stands with different topographic characteristics can show different responses to climate change.

Here, we quantify decadal changes in AGB and their processes in relation to endogenous processes and climatic factors, using tree census data measured repeatedly over 26 years (1993-2019) in an old-growth, cool-temperate deciduous mixed forest with different types of topographic units in northern Japan. We ask the following questions: (1) Did AGB show net increase or decrease over the whole forest and study period? (2) Did tree species contribute differently to biomass change among the different types of topographic units? (3) How did gain and loss contribute to the overall changes in stand biomass? (4) Did climatic factors and endogenous processes such as canopy gap formation and recovery influence short-term changes in AGB at the local scale?

\section{Materials and methods}

\section{Study site}

The study was conducted in the Kanumazawa Riparian Research Forest (KRRF) in Iwate, northern Japan $\left(39^{\circ} 06^{\prime} \mathrm{N}, 140^{\circ} 51^{\prime} \mathrm{E}\right)$, an old-growth forest with no record of significant anthropogenic disturbances. In KRRF, tree community dynamics have been repeatedly measured since the establishment of a 4.71-ha permanent plot in 1993 (Fig. 1; Suzuki et al. 2002). This site is one of the core research sites of the Japan Long-Term Ecological Research Network (JaLTER). KRRF has a cool-temperate climate with a mean annual temperature of $8.8^{\circ} \mathrm{C}$ and a warmth index (Kira 1991) of $71^{\circ} \mathrm{C}$ month (Noguchi et al. unpublished). The mean annual precipitation is $2000 \mathrm{~mm}$, and snow cover lasts 5 months with maximum snow depth of approximately $2 \mathrm{~m}$ (Oki et al. 2013). The vegetation depends on the topographic unit. The riparian area is covered with a species-rich deciduous broadleaved forest consisting of both riparian specialists (Cercidiphyllum japonicum, Aesculus turbinata, Acer mono, Pterocarya rhoifolia, and Ulmus laciniata) and habitat generalists (Fagus crenata and Quercus crispula) (Masaki et al. 2008; Suzuki et al. 2002). The upper slopes and terrace are dominated by $F$. crenata and $Q$. crispula. Detailed information on the ecology of component species is available in Hoshizaki et al. (1997, 1999), Masaki et al. (2005), and Osumi (2006). The age of the largest $C$. japonicum individual is estimated to be more than 500 years (Osumi 2006), indicating that this forest is sufficiently old-growth. The natural disturbance regime in KRRF is characterized by canopy gap formation and fluvial sediment movements (Oki et al. 2013). Gap-creating disturbance occurs about every 1 to 3 years, with gap size ranging from 
tens to hundreds of square meters (Oki et al. 2013). Recent fluvial sediment movements were recorded in 1988, 1998, and 2007, causing ground disturbance with sizes ranging from 144 $\mathrm{m}^{2}$ to $680 \mathrm{~m}^{2}$ but no damage to canopy trees.

\section{Field measurement}

The 4.71-ha permanent plot was divided to $47110-\mathrm{m} \times 10-\mathrm{m}$ quadrats (Fig. 1). The plot ranges in elevation from 400 to $460 \mathrm{~m}$ a.s.l., and includes three topographic units: riparian (3.11 ha), terrace (1.06 ha), and denuded slope between them (0.57 ha). In the whole plot, all stems greater than $5 \mathrm{~cm}$ in diameter at breast height $(\mathrm{DBH})$ were tagged for identification and mapped, and DBH was measured at the same marked location on each stem every 2 years from 1993 to 1999 and every 4 years from then to 2019.

\section{Estimation of AGB change and its components}

We calculated tree AGB, basal area (BA), and stem density in each topographic unit. Individual tree AGB was estimated by using a general allometric equation for tree species in Japan (Ishihara et al. 2015):

$$
\begin{aligned}
\ln (y)= & -1.196+1.162 \times \ln (D)+0.338 \times(\ln (D))^{2} \\
& -0.044 \times(\ln (D))^{3}+0.708 \times \ln (\rho)
\end{aligned}
$$

where $y$ is $\mathrm{AGB} ; D$ is stem DBH, and $\rho$ is the wood specific gravity of each species (Editorial Board of Wood Industry 1966; Kurokawa et al. unpublished; Fujiwara et al. 2007).

Confidence intervals of changes in AGB, BA, and stem density were estimated via bootstrapping across $10-\mathrm{m} \times 10-\mathrm{m}$ quadrats following the method of Valencia et al. (2009).

To overview trends in AGB change during the study period and net annual change in AGB, we calculated AGB for three tree size classes: large ( $\geq 50 \mathrm{~cm} \mathrm{DBH})$, medium (15-50 cm DBH), and small (5-15 cm DBH). The net annual change in AGB (in $\mathrm{Mg} \mathrm{ha}^{-1} \mathrm{y}^{-1}$ ) was calculated each 4-year period from 1996 to 2019 from the tree DBH data of 1995 to 2019. It was then dissected into annual AGB gain and annual AGB loss. Annual AGB gain was calculated separately for growth of trees in each size class and ingrowth, and AGB loss was calculated for mortality of trees in each size class.

\section{Analysis of factors affecting short-term AGB gain at local scale}

We examined the effects of climatic condition in each measurement period, canopy gap formation and topography on local-scale AGB gain using two generalized linear mixed-effect 

models (GLMMs). For both models, variables were calculated for every 20-m × 20-m subplot in each 4-year period from 1996 to 2019. Subplot size was determined as an appropriate area to detect gap formation and subsequent recovery in consideration of the range of gap size in KRRF. Both models used AGB gain as the response variable and included subplot as a random effect.

In model 1, we aimed to investigate whether the amount of AGB gain differed among the measurement periods with the effects of topographic unit and gap formation in the current and previous measurement periods. Fixed effects were initial AGB in the current measurement period, AGB losses in the current and previous measurement periods, topographic unit, and the five 4-year measurement periods between 2000 and 2019, with topographic unit and measurement period as categorical variables. Initial AGB was included as it is expected to be the "capital" for AGB gain by tree growth. AGB losses were indices of gap formation in the current and previous measurement periods.

In model 2, the effect of climate was analyzed separately from the effect of measurement period to avoid multicollinearity. Fixed effects were initial AGB in the current measurement period, AGB loss in the current and previous measurement periods, topographic unit, and mean temperature during the previous autumn (September-November) and the current summer (June-August) over the measurement periods. Both types of mean temperature have a major influence on annual DBH growth of individual trees in most dominant species of KRRF (Matsushita et al. manuscript in preparation). As the on-site temperature data do not cover the entire study period, we used data from the nearest weather station, at Wakayanagi $\left(39^{\circ} 08^{\prime} \mathrm{N}, 141^{\circ} 04^{\prime} \mathrm{E} ; 97 \mathrm{~m}\right.$ a.s.1.: Japan Meteorological Agency, https://www.data.jma.go.jp/ gmd/risk/obsdl/index.php), $18 \mathrm{~km}$ east of the study site. These models were fitted by the $1 \mathrm{me} 4$ v. 1.1-21 package (Bates et al. 2015) in R 3.6.3 (R Core Team 2020). To evaluate the variance explained by the models, we calculated two $R^{2}$ values for mixed-effect models following the method of Nakagawa et al. (2017): marginal $R^{2}\left(R^{2} \mathrm{GLMM}(\mathrm{m})\right)$, which is the proportion of the variance explained by fixed effects, and conditional $R^{2}\left(R^{2} \mathrm{GLMM}(\mathrm{c})\right)$, which is the proportion of the variance explained by both fixed and random effects. These were calculated by the MuMIn v. 1.43.15 package (Bartoń 2019) in R.

\section{Results}

\section{Overall changes in AGB at plot scale}

BA in 1993 was greatest in the riparian unit $\left(34.2 \mathrm{~m}^{2} \mathrm{ha}^{-1}\right)$ and least in the denuded slope unit 
161 (Table 1). From 1993 to 2019, BA increased significantly in all topographic units. AGB was 162 greatest in the terrace unit (246.0 $\left.\mathrm{Mg} \mathrm{ha}^{-1}\right)$ at the beginning of the study period (Table 1). It increased significantly in all topographic units during the study period, increasing in most 4year periods except for some short pauses; for instance, from 2011 to 2015 in the riparian and denuded slope units (Fig. 2). AGB of large trees ( $\geq 50 \mathrm{~cm} \mathrm{DBH})$ in 1993 occupied $76.7 \%$ of total AGB in riparian, $70.6 \%$ in denuded slope, and $77.7 \%$ in terrace units. Trends of increasing total AGB in the riparian and terrace units were similar to those of large-tree AGB. During the study period, stem density declined in the riparian and terrace units but increased in the denuded slope unit (Table 1). The change in stem density was significant only in the riparian unit.

In the riparian unit, $C$. japonicum had the largest $\mathrm{AGB}$ at the beginning of the study period, followed by F. crenata, A. turbinata, Q. crispula, and A. mono (Table 2). AGB of these species, except for Q. crispula, increased during the study period. Pterocarya rhoifolia had the greatest increment in AGB over the study period, accounting for $52.3 \%$ of the total increment in the riparian unit, followed by $A$. turbinata at $25.4 \%$. In contrast, several other species with relatively small AGB at the beginning, such as Zelkova serrata and Ulmus laciniata, showed a decline in AGB during the study period. The denuded slope and terrace units were dominated by $F$. crenata and $Q$. crispula, and the denuded slope by $A$. mono as well (Table 2). All these species had an increase in AGB during the study period, maintaining the AGB-based rank of species composition.

Annual gain in AGB remained at approximately $3 \mathrm{Mg} \mathrm{ha}^{-1} \mathrm{y}^{-1}$ with some differences among the measurement periods: larger in 2008-2011 and 2016-2019 and smaller in 20042007 in all topographic units (Fig. 3). In the riparian and terrace units, large- and mediumsized trees accounted for most of the annual gain. Annual losses in AGB fluctuated among the 4-year periods, and were largest in 2012-2015 in all topographic units. Regardless of topographic unit, measurement periods with greater loss of AGB of large trees tended to have greater total loss of AGB. As a consequence, net annual change in AGB ranged from -0.6 to

$188+2.6 \mathrm{Mg} \mathrm{ha}^{-1} \mathrm{y}^{-1}$ but stayed positive except in 2012 to 2015 in the riparian and denuded slope 189 units.

\section{Effects of climate and gap formation on short-term AGB gain at local scale}

191 Local-scale AGB gain in the 20-m $\times 20$-m subplots was positively influenced by initial AGB

192 in each measurement period (GLMM model 1: Table 3, Fig. 4). It was significantly greater in 193 subplots with larger AGB loss in the previous measurement period but smaller in subplots 
194 with larger AGB loss in the current measurement period. It was not significantly affected by

195 topographic unit. It differed significantly among the measurement periods: smaller in 2004-

1962007 and larger in 2008-2011 and 2016-2019. In model 1, $R^{2}{ }_{\mathrm{GLMM}(\mathrm{m})}=0.31$ and $R^{2}{ }_{\mathrm{GLMM}(\mathrm{c})}=$

1970.76 , indicating that $31 \%$ of the variation was explained by fixed effects and $76 \%$ by fixed

198 and random effects. In model 2 (Table 4), the effects of initial AGB, AGB loss in the current

199 and previous measurement periods, and topographic unit were almost identical to those in

200 model 1. Local-scale AGB gain was larger in measurement periods with higher mean

201 temperature during the current summer but smaller in those with higher mean temperature

202 during the previous autumn. Model 2 explained almost identical variation as model 1, with

$203 \quad R^{2}{ }_{\mathrm{GLMM}(\mathrm{m})}=0.32$ and $R_{\mathrm{GLMM}(\mathrm{c})}^{2}=0.77$.

\section{Discussion}

205 AGB of KRRF increased steadily over the 26 years in all topographic units, with increments

206 of 30 to $35 \mathrm{Mg} \mathrm{ha}^{-1}$ in each (Table 1). BA also increased over the study period, even though it 207 was initially equivalent to values reported in other cool-temperate old-growth forests in Japan

208 (Masaki et al. 1992; Nakashizuka 1988; Seiwa et al. 2013), indicating that the forest had

209 already been well stocked. These results are consistent with reports that temperate old-growth

210 forests continuously gain biomass over the long term (Keeton et al. 2011; Luyssaert et al.

211 2008). This continuous stand-scale biomass increment was attributable mainly to an increase

212 in AGB of large trees, in agreement with the reported global importance of large trees in

213 determining stand AGB (Lutz et al. 2018; Slik et al. 2013).

214 Patterns of tree growth or stand-biomass-change vary across tree species composition and

215 diversity, as well as with environmental conditions such as topography (Kubota et al. 2004;

216 Valencia et al. 2009). In KRRF, topography was reported to determine tree species

217 distribution through affecting seedling survival differently across species (Masaki et al. 2005).

218 Here, however, a steady increase in AGB was common to all three topographic units (Table 1;

219 Fig. 2), despite the difference in tree species composition among them (Table 2). In addition,

220 local-scale AGB gain did not differ among the topographic units (Table 3). We attribute this

221 similarity to the distinct AGB increment in F. crenata, which is dominant in all three

222 topographic units (Table 2). A growing abundance of $F$. crenata is documented in several

223 stable old-growth forest (Seiwa et al. 2013; Yamamoto and Nishimura 1999). Increases in

224 both AGB and stem density of F. crenata in KRRF may be due to lack of remarkable

225 disturbance even in the riparian unit during the study period. Pterocarya rhoifolia, a riparian

226 specialist of cool-temperate forests in Japan (Sakio et al. 2002), made the largest contribution 
to the stand AGB increment in the riparian unit (Table 2). Despite the substantial decline in its stem density (Appendix 1), its AGB at the end of the study period was 3 times the initial value. It is likely that the fast growth of $P$. rhoifolia (Sakio 1993) is associated with its rapid increase in AGB. Although AGB decreased in some species such as Z. serrata and $U$. laciniata in the riparian unit, P. rhoifolia compensated for the decrease and resulted in the stand-level AGB increase.

Mortality is the major cause of reduced growth or decline in AGB (Schuster et al. 2008;

$234 \mathrm{Xu}$ et al. 2012). Although large disturbances such as strong typhoons, insect outbreaks, or severe flooding in the riparian unit were not recorded during the 26 years, the loss of AGB varied substantially among the topographic units and among the 4-year measurement periods (Fig. 3). These variations were explained mainly by the spatio-temporal variation in mortality of large trees. A significant contribution of large-tree mortality to the AGB loss has also been reported in other old-growth forests (Hoshizaki et al. 2004). Despite these temporal and spatial variations, the AGB loss generally remained smaller than the AGB gain, bringing about a positive change in AGB in most of the measurement periods. The temporal change of stand-level AGB appears to be inconsistent with the assumed long-term balance between biomass loss caused by canopy gap formation and subsequent gain during gap recovery.

In contrast to AGB loss, temporal fluctuations in AGB gain were generally synchronized across the topographic units at the stand scale (Fig. 3). The results of model 1 indicate that local-scale AGB gain also differed among measurement periods even after adjustment for initial AGB and disturbance during each period (Table 3). As expected, initial AGB positively influenced local-scale AGB gain (Fig.4). Larger AGB loss in the previous measurement period caused greater AGB gain, suggesting that variations in local-scale AGB gain are partially explained by recovery in and around canopy gaps. Local-scale AGB gain also substantially differed among the measurement periods. The results of model 2 suggest that the observed temporal variations in AGB gain are caused by climatic factors: a hotter current summer had positive effects whereas a warmer previous autumn had negative effects on AGB gain (Table 4). The positive response to high temperature in the growing season is consistent with the trends of individual-tree growth observed in deciduous broadleaved species in KRRF (Matsushita et al. manuscript in preparation) and other cool-temperate forests in Japan (Hiura et al. 2019). The negative effect of a warmer autumn on growth is also found in individualtree growth in KRRF (Matsushita et al. manuscript in preparation) and may be caused by a larger increment in respiration than in photosynthesis (Piao et al. 2008).

Our models explained a considerable amount of variation in local AGB gain, although the 
analysis did not include other potential factors that enhance tree growth such as change in precipitation (Hiura et al. 2019), rising $\mathrm{CO}_{2}$ levels in the atmosphere (e.g., Norby et al. 2005), and nitrogen deposition (Thomas et al. 2010). The temperature at the weather station nearest to KRRF shows a substantial rise in summer and autumn temperatures over the past 40 years (Appendix 2). Decadal climate trends of warming are likely to have contributed to the observed steady increase in AGB in KRRF by providing favorable conditions for tree growth in the study period. Warming-induced growth acceleration in the past several decades has been reported in temperate and boreal forests in Europe (Kauppi et al. 2014; Pretzsch et al. 2014). In Japan, some cool-temperate beech-dominated forests are predicted to be vulnerable to warming (Matsui et al. 2009). Accumulation of tree growth data from a broader range of temperatures across cool-temperate forests in Japan will improve our understanding of the influence of climate change on this type of forest.

\section{3}

\section{Acknowledgements}

We thank many colleagues, including Gaku Hitsuma, Chinatsu Homma, Shoji Naoe, Takayuki Ota and Takanobu Yagi for field assistance. We also thank Haruko Narita and Saori Sato for data preparation. Part of the data of this study was obtained from the Monitoring Sites 1000 Project of the Ministry of the Environment, Japan. This study was partly supported by JSPS KAKENHI Grant Numbers 15H04517, 19H02999 and 21H04946. We have no conflict of interest to declare.

\section{References}

Bartoń K (2019) Package 'MuMIn'. Multi-Model Inference.

Bates D, Mächler M, Bolker B, Walker S (2015) Fitting linear mixed-effects models using lme4. 2015 67:48. https://doi.org/10.18637/jss.v067.i01

Bormann FH, Likens GE (1979) Pattern and process in a forested ecosystem : disturbance, development, and the steady state based on the Hubbard Brook ecosystem study. Springer-Verlag, New York, USA

Chen HYH, Luo Y (2015) Net aboveground biomass declines of four major forest types with forest ageing and climate change in western Canada's boreal forests. Global Change Biol 21:3675-3684. https://doi.org/10.1111/gcb.12994

Chen HYH, Luo Y, Reich PB, Searle EB, Biswas SR (2016) Climate change-associated trends in net biomass change are age dependent in western boreal forests of Canada. Ecol Lett 19:1150-1158. https://doi.org/10.1111/ele.12653

Editorial Board of Wood Industry (1966) Wood Materials of Japan. Wood Technological Association of Japan, Tokyo (in Japanese) 
Foster JR, D'Amato AW, Bradford JB (2014) Looking for age-related growth decline in natural forests: unexpected biomass patterns from tree rings and simulated mortality. Oecologia 175:363-374. https://doi.org/10.1007/s00442-014-2881-2

Fujiwara T, Yamashita K, Kuroda K (2007) Basic densities as a parameter for estimating the amount of carbon removal by forests and their variation. Bulletine of FFPRI 6: 215-226.

Hiura T, Go S, Iijima H (2019) Long-term forest dynamics in response to climate change in northern mixed forests in Japan: A 38-year individual-based approach. For Ecol Manage 449: 117469. https://doi.org/10.1016/j.foreco.2019.117469

Hoshizaki K, Suzuki W, Sasaki S (1997) Impacts of secondary seed dispersal and herbivory on seedling survival in Aesculus turbinata. J Veg Sci 8:735-742

Hoshizaki K, Suzuki W, Nakashizuka T (1999) Evaluation of secondary dispersal in a large-seeded tree Aesculus turbinata: a test of directed dispersal. Plant Ecol 144:167-176. https://doi.org/10.1023/a:1009816111057

Hoshizaki K, Niiyama K, Kimura K, Yamashita T, Bekku Y, Okuda T, Quah ES, Noor NSM (2004) Temporal and spatial variation of forest biomass in relation to stand dynamics in a mature, lowland tropical rainforest, Malaysia. Ecol Res 19: 357-363. https://doi.org/10.1111/j.14401703.2004.00645.x

Ishihara MI, Utsugi H, Tanouchi H, Aiba M, Kurokawa H, Onoda Y, Nagano M, Umehara T, Ando M, Miyata R, Hiura T (2015) Efficacy of generic allometric equations for estimating biomass: a test in Japanese natural forests. Ecol Appl 25:1433-1446. https://doi.org/10.1890/14-0175.1

Kauppi PE, Posch M, Pirinen P (2014) Large Impacts of Climatic Warming on Growth of Boreal Forests since 1960. PLOS ONE 9:e111340. https://doi.org/10.1371/journal.pone.0111340

Keeton WS, Whitman AA, McGee GC, Goodale CL (2011) Late-Successional Biomass Development in Northern Hardwood-Conifer Forests of the Northeastern United States. For Sci 57:489-505. https://doi.org/10.1093/forestscience/57.6.489

Kira T (1991) Forest ecosystems of east and southeast Asia in a global perspective. Ecol Res 6:185-200. https://doi.org/10.1007/BF02347161

Kubota Y, Murata H, Kikuzawa K (2004) Effects of topographic heterogeneity on tree species richness and stand dynamics in a subtropical forest in Okinawa Island, southern Japan. J Ecol 92:230-240.

Kuuluvainen T, Hofgaard A, Aakala T, Gunnar Jonsson B (2017) North Fennoscandian mountain forests: History, composition, disturbance dynamics and the unpredictable future. For Ecol Manage 385:140-149. http://dx.doi.org/10.1016/j.foreco.2016.11.031

Lutz JA, Furniss TJ, Johnson DJ et al. (2018) Global importance of large-diameter trees. Global Ecol Biogeogr 27:849-864. https://doi.org/10.1111/geb.12747

Luyssaert S, Schulze ED, Börner A, Knohl A, Hessenmöller D, Law BE, Ciais P, Grace J (2008) Oldgrowth forests as global carbon sinks. Nature 455:213-215. 
Masaki T, Osumi K, Takahashi K, Hozshizaki K (2005) Seedling dynamics of Acer mono and Fagus crenata: an environmental filter limiting their adult distributions. Plant Ecol 177:189-199. https://doi.org/10.1007/s11258-005-2177-z

Masaki T, Osumi K, Hoshizaki K, Hosino D, Takahashi K, Matsune K, Suzuki W (2008) Diversity of tree species in mountain riparian forest in relation to disturbance-mediated microtopography. In: Sakio H, Tamura T (eds) Ecology of Riparian Forests in Japan: Disturbance, Life History, and Regeneration. Springer Japan, Tokyo, pp 251-266

Matsui T, Takahashi K, Tanaka N, Hijioka Y, Horikawa M, Yagihashi T, Harasawa H (2009) Evaluation of habitat sustainability and vulnerability for beech (Fagus crenata) forests under 110 hypothetical climatic change scenarios in japan. Appl Veg Sci 12:328-339. https://doi.org/10.1111/j.1654109X.2009.01027.x

McDowell NG, Allen CD, Anderson-Teixeira K et al. (2020) Pervasive shifts in forest dynamics in a changing world. Science 368:eaaz9463. https://doi.org/10.1126/science.aaz9463

Nakagawa S, Johnson PCD, Schielzeth H (2017) The coefficient of determination R(2) and intra-class correlation coefficient from generalized linear mixed-effects models revisited and expanded. J R Soc Interface 14:20170213. https://doi.org/10.1098/rsif.2017.0213

Nakamura F, Inahara S (2007) Fluvial Geomorphic Disturbances and Life History Traits of Riparian Tree Species. In: Johnson EA, Miyanishi K (eds) Plant Disturbance Ecology. Academic Press, Burlington, pp 283-310. https://doi.org/10.1016/b978-012088778-1/50011-x

Nakashizuka T (1988) Regeneration of beech (Fagus crenata) after the simultaneous death of undergrowing dwarf bamboo (Sasa kurilensis). Ecol Res 3:21-35. https://doi.org/10.1007/bf02348692

Norby RJ, Delucia EH, Gielen B et al. (2005) Forest response to elevated $\mathrm{CO}_{2}$ is conserved across a broad range of productivity. Proc Natl Acad Sci U S A 102:18052-18056. https://doi.org/10.1073/pnas.0509478102

Odum EP (1969) The strategy of ecosystem development. Science 164:262-270. https://doi.org/10.1126/science.164.3877.262

Ohmann JL, Spies TA (1998) Regional gradient analysis and spatial pattern of woody plant communities of Oregon forests. Ecol Monogr 68:151-182. https://doi.org/10.1890/00129615(1998)068[0151:Rgaasp]2.0.Co;2

Oki S, Akiyoshi T, Hoshino D, Shibata M, Matsushita M, Hoshizaki K (2013) Interactive effect of canopy and fluvial disturbances on sapling community structure and species diversity in a montane riparian forest. Ecoscience 20:194-203. https://doi.org/10.2980/20-2-3609

Osumi K (2006) Life history of Cercidiphyllum japonicum: the paradox of early-seral species as a component of climax forest. In: Masaki T, Tanaka H, Shibata M (eds) Forest ecology, with longterm perspectives. Bun-ichi Sogo Shuppan, Tokyo (in Japanese) biomass stocks and dynamics in Andean forests. Plant Ecol 219:1481-1492. https://doi.org/10.1007/s11258-018-0895-2 
Phillips OL, Higuchi N, Vieira S, Baker TR, Chao K-J, Lewis SL (2009) Changes in Amazonian Forest

Biomass, Dynamics, and Composition, 1980-2002. Amazonia and Global Change https://doi.org/10.1029/2008GM000779, pp 373-387

Piao S, Ciais P, Friedlingstein P et al. (2008) Net carbon dioxide losses of northern ecosystems in response to autumn warming. Nature 451:49-52. http://dx.doi.org/10.1038/nature06444

Pretzsch H, Biber P, Schütze G, Uhl E, Rötzer T (2014) Forest stand growth dynamics in Central Europe have accelerated since 1870. Nature Communications 5:4967. https://doi.org/10.1038/ncomms5967

R Core Team (2020) R: A language and environment for statistical computing. R Foundation for Statistical Computing, Vienna, Austria

Sakio H (1993) Sapling growth patterns in Fraxinus platypoda and Pterocarya rhoifolia. Jap J Ecol 43:163-167. https://doi.org/10.18960/seitai.43.3_163 (in Japanese with English summary)

Sakio H (2020) Long-Term Ecosystem Changes in Riparian Forests. Springer, Singapore. https://doi.org/10.1007/978-981-15-3009-8

Sakio H, Kubo M, Shimano K, Ohno K (2002) Coexistence of three canopy tree species in a riparian forest in the Chichibu Mountains, Central Japan. Folia Geobot 37:45-61. https://doi.org/10.1007/Bf02803190

Schuster WSF, Griffin KL, Roth H, Turnbull MH, Whitehead D, Tissue DT (2008) Changes in composition, structure and aboveground biomass over seventy-six years (1930-2006) in the Black Rock Forest, Hudson Highlands, southeastern New York State. Tree Physiology 28:537549. https://doi.org/10.1093/treephys/28.4.537

Seiwa K, Miwa Y, Akasaka S, Kanno H, Tomita M, Saitoh T, Ueno N, Kimura M, Hasegawa Y, Konno M, Masaka K (2013) Landslide-facilitated species diversity in a beech-dominant forest. Ecol Res 28:29-41. https://doi.org/10.1007/s11284-012-0996-7

Slik JWF, Paoli G, McGuire K et al. (2013) Large trees drive forest aboveground biomass variation in moist lowland forests across the tropics. Global Ecol Biogeogr 22:1261-1271. https://doi.org/10.1111/geb.12092

Suzuki W, Osumi K, Masaki T, Takahashi K, Daimaru H, Hoshizaki K (2002) Disturbance regimes and community structures of a riparian and an adjacent terrace stand in the Kanumazawa Riparian Research Forest, northern Japan. For Ecol Manage 157:285-301. https://doi.org/10.1016/s03781127(00)00667-8

Thomas RQ, Canham CD, Weathers KC, Goodale CL (2010) Increased tree carbon storage in response to nitrogen deposition in the US. Nature Geoscience 3:13-17. https://doi.org/10.1038/ngeo721

Valencia R, Condit R, Muller-Landau HC, Hernandez C, Navarrete H (2009) Dissecting biomass dynamics in a large Amazonian forest plot. J Trop Ecol 25:473-482. https://doi.org/10.1017/S0266467409990095

Xu C-Y, Turnbull MH, Tissue DT, Lewis JD, Carson R, Schuster WSF, Whitehead D, Walcroft AS, Li J, Griffin KL (2012) Age-related decline of stand biomass accumulation is primarily due to mortality and not to reduction in NPP associated with individual tree physiology, tree growth or 
413 Yamamoto S, Nishimura N (1999) Canopy gap formation and replacement pattern of major tree species among developmental stages of beech (Fagus crenata) stands, Japan. Plant Ecol 140:167-176. https://doi.org/10.1023/A:1009713002039 
Tables

417 Table 1. Basal area, aboveground biomass, and stem density at the study site at the beginning (1993) and end (2019) of the study period with overall changes in three

418 topographic units (riparian, denuded slope, and terrace).

\begin{tabular}{lccc}
\hline & 1993 & 2019 & Change \\
\hline Basal area $\left(\mathrm{m}^{2} \mathrm{ha}^{-1}\right)$ & $34.2(28.7-40.5)$ & $38.6(32.4-457.7)$ & $4.5(2.4-6.5)$ \\
$\quad$ Riparian & $21.5(15.3-28.3)$ & $26.6(20.2-33.8)$ & $5.1(2.2-7.8)$ \\
$\quad$ Denuded slope & $32.3(26.6-37.7)$ & $32.3(26.6-37.7)$ & $4.3(1.5-6.7)$ \\
$\quad$ Terrace & & & \\
Aboveground biomass $\left(\mathrm{Mg} \mathrm{ha}^{-1}\right)$ & $244.1(202.7-289.4)$ & $274.2(230.1-326.2)$ & $30.1(14.0-45.6)$ \\
$\quad$ Riparian & $156.8(100.3-216.0)$ & $191.5(136.1-252.7)$ & $34.7(13.2-56.1)$ \\
$\quad$ Denuded slope & $246.0(202.4-293.5)$ & $276.7(225.8-336.4)$ & $30.6(8.0-53.4)$ \\
$\quad$ Terrace & $583(519-648)$ & $509(452-581)$ & $-73(-111$ to -36$)$ \\
Stem density (stems ha $\left.{ }^{-1}\right)$ & $781(637-939)$ & $877(704-1046)$ & $96(-35$ to 235) \\
Riparian & $952(833-1061)$ & $906(785-1031)$ & $-47(-118$ to 24) \\
Denuded slope & & & \\
Terrace & & &
\end{tabular}

419 Values in parentheses are $95 \%$ confidence intervals. When CIs do not include 0 , the changes are significant. 
Table 2. Overall changes in aboveground biomass ( $\mathrm{AGB}$, in $\mathrm{Mg} \mathrm{ha}^{-1}$ ) of component tree species in each topographic unit during the study period and the relative

contribution of each species to the total change in AGB. Species are listed in the order of AGB in 1993 in the entire plot

\begin{tabular}{|c|c|c|c|c|c|c|c|c|c|c|c|c|}
\hline \multirow[t]{2}{*}{ Species } & \multicolumn{4}{|c|}{ Riparian } & \multicolumn{4}{|c|}{ Denuded slope } & \multicolumn{4}{|c|}{ Terrace } \\
\hline & 1993 & 2019 & Change & $\begin{array}{c}\text { Contribution } \\
(\%)\end{array}$ & 1993 & 2019 & Change & $\begin{array}{c}\text { Contribution } \\
(\%)\end{array}$ & 1993 & 2019 & Change & $\begin{array}{c}\text { Contribution } \\
(\%)\end{array}$ \\
\hline Fagus crenata & 52.1 & 56.2 & 4.1 & 13.7 & 68.9 & 80.4 & 11.5 & 33.2 & 139.3 & 153.9 & 14.7 & 47.9 \\
\hline Quercus crispula & 30.6 & 30.3 & -0.2 & -0.8 & 30.4 & 37.8 & 7.4 & 21.2 & 82.1 & 86.3 & 4.2 & 13.7 \\
\hline $\begin{array}{l}\text { Cercidiphyllum } \\
\text { japonicum }\end{array}$ & 58.9 & 61.9 & 3.0 & 10.1 & 0.0 & 0.0 & 0.0 & 0.0 & 0.0 & 0.0 & 0.0 & 0.0 \\
\hline Aesculus turbinata & 47.8 & 55.5 & 7.6 & 25.4 & 3.8 & 5.4 & 1.6 & 4.5 & 0.0 & 0.0 & 0.0 & 0.0 \\
\hline Acer mono & 21.0 & 21.6 & 0.5 & 1.8 & 28.9 & 38.0 & 9.0 & 26.1 & 0.2 & 0.4 & 0.2 & 0.6 \\
\hline Pterocarya rhoifolia & 8.6 & 24.4 & 15.8 & 52.4 & 0.9 & 3.7 & 2.8 & 8.0 & 0.0 & 0.0 & 0.0 & 0.0 \\
\hline Zelkova serrata & 5.7 & 4.7 & -1.0 & -3.2 & 2.0 & 3.6 & 1.5 & 4.4 & 0.0 & 0.0 & 0.0 & 0.0 \\
\hline Ulmus laciniata & 4.8 & 2.8 & -2.0 & -6.6 & 0.0 & 0.0 & 0.0 & 0.0 & 0.0 & 0.0 & 0.0 & 0.0 \\
\hline Magnolia obovata & 4.2 & 6.0 & 1.8 & 6.1 & 0.0 & 0.5 & 0.4 & 1.3 & 1.2 & 2.2 & 1.0 & 3.3 \\
\hline Kalopanax pictus & 4.5 & 5.0 & 0.5 & 1.8 & 0.1 & 0.7 & 0.6 & 1.7 & 0.0 & 0.3 & 0.3 & 0.9 \\
\hline Acer sieboldianum & 0.4 & 0.1 & -0.3 & -1.1 & 4.5 & 3.5 & -1.0 & -2.9 & 6.0 & 8.0 & 2.0 & 6.5 \\
\hline Acer japonicum & 0.5 & 0.9 & 0.4 & 1.3 & 1.9 & 2.4 & 0.5 & 1.5 & 6.0 & 7.4 & 1.4 & 4.5 \\
\hline Others & 5.0 & 4.8 & -0.2 & -0.8 & 15.3 & 15.7 & 0.4 & 1.1 & 11.2 & 18.1 & 6.9 & 22.5 \\
\hline$\overline{\text { Total }}$ & 244.1 & 274.2 & 30.1 & 100.0 & 156.8 & 191.5 & 34.7 & 100.0 & 246.0 & 276.7 & 30.6 & 100.0 \\
\hline
\end{tabular}


Table 3. Results of the generalized linear mixed-effect model (model 1) testing the effects of initial aboveground biomass (AGB), canopy gap formation, topographic

425 unit, and measurement period on the AGB gain in $20-\mathrm{m} \times 20-\mathrm{m}$ subplots.

\begin{tabular}{llrcrrr}
\hline & & Estimate & Standard error & $\mathrm{df}$ & $t$-value & $P$-value \\
\hline Intercept & & 0.259 & 0.033 & 148.7 & 7.868 & $<0.001$ \\
Initial AGB & 0.021 & 0.003 & 135.8 & 8.255 & $<0.001$ \\
AGB loss by mortality & Previous & 0.016 & 0.006 & 511.7 & 2.819 & 0.005 \\
& Current & -0.017 & 0.006 & 481.0 & -2.782 & 0.006 \\
Topographic unit & Denuded slope & 0.023 & 0.047 & 109.3 & 0.501 & 0.618 \\
(v. Riparian) & Terrace & -0.018 & 0.039 & 109.0 & -0.461 & 0.646 \\
Measurement period & $2004-2007$ & -0.050 & 0.015 & 442.1 & -3.301 & 0.001 \\
(v. 2000-2003) & $2008-2011$ & 0.038 & 0.015 & 445.1 & 2.514 & 0.012 \\
& $2012-2015$ & -0.005 & 0.015 & 450.5 & -0.327 & 0.743 \\
& $2016-2019$ & 0.040 & 0.015 & 455.9 & 2.606 & 0.009 \\
\hline
\end{tabular}



unit, and climate (mean air temperature) of each measurement period on the AGB gain in $20-\mathrm{m} \times 20$-m subplots.

\begin{tabular}{llcccrc}
\hline & & Estimate & Standard error & $\mathrm{df}$ & $t$-value & $P$-value \\
\hline Intercept & -0.559 & 0.321 & 445.1 & -1.738 & 0.083 \\
Initial AGB & 0.021 & 0.003 & 137.9 & 8.294 & $<0.001$ \\
AGB loss by mortality & Previous & 0.016 & 0.006 & 508.0 & 2.925 & 0.004 \\
& Current & -0.015 & 0.006 & 481.7 & -2.550 & 0.011 \\
Topographic unit & Denuded slope & 0.023 & 0.047 & 109.4 & 0.498 & 0.619 \\
(v. Riparian) & Terrace & -0.018 & 0.038 & 109.1 & -0.462 & 0.645 \\
Mean air temperature & Previous autumn & -0.137 & 0.023 & 443.0 & -5.865 & $<0.001$ \\
& Current summer & 0.120 & 0.021 & 450.8 & 5.803 & $<0.001$ \\
\hline
\end{tabular}




\section{$431 \quad$ Figure legends}

432 Fig. 1. Topographic map of the Kanumazawa Riparian Research Forest (KRRF). The solid frame

433 represents the 4.71-ha KRRF plot. Colors denote the three topographic units: blue, riparian (3.11 ha);

434 orange, denuded slope ( $0.57 \mathrm{ha})$; green, terrace (1.06 ha). Black dotted lines show the $10-\mathrm{m} \times 10-\mathrm{m}$

435 quadrats; thin red lines show the 20 - $\mathrm{m} \times 20$ - $\mathrm{m}$ subplots. Contour interval is $2 \mathrm{~m}$.

436 Fig. 2. Trends in total aboveground biomass (AGB) over 26 years in the three topographic units. AGB is

437 shown for stand total and stems in three size classes: large (diameter at breast height $[\mathrm{DBH}] \geq 50 \mathrm{~cm}$ ),

438 medium (DBH, 15-50 cm), and small (DBH, 5-15 cm).

439 Fig. 3. Components of average annual change in aboveground biomass (AGB) by each measurement period

440 in the three topographic units. Blue bars (4 levels of color gradient) denote annual AGB gain from growth

441 of surviving stems in the three size classes (large, diameter at breast height [DBH] $\geq 50 \mathrm{~cm}$; medium, 15-

$44250 \mathrm{~cm} \mathrm{DBH}$; small, 5-15 cm DBH) and ingrowth. Orange bars (3 levels of color gradient) denote annual

443 AGB loss from stems that died during each measurement period in the three size classes. Dark gray bars

444 denote net average annual change in AGB.

445 Fig. 4. Local-scale aboveground biomass (AGB) gain per 4-year measurement period in relation to initial

446 AGB of measurement period. Colors represent classes of AGB loss in previous measurement period;

447 symbols represent measurement periods. 
Fig. 1

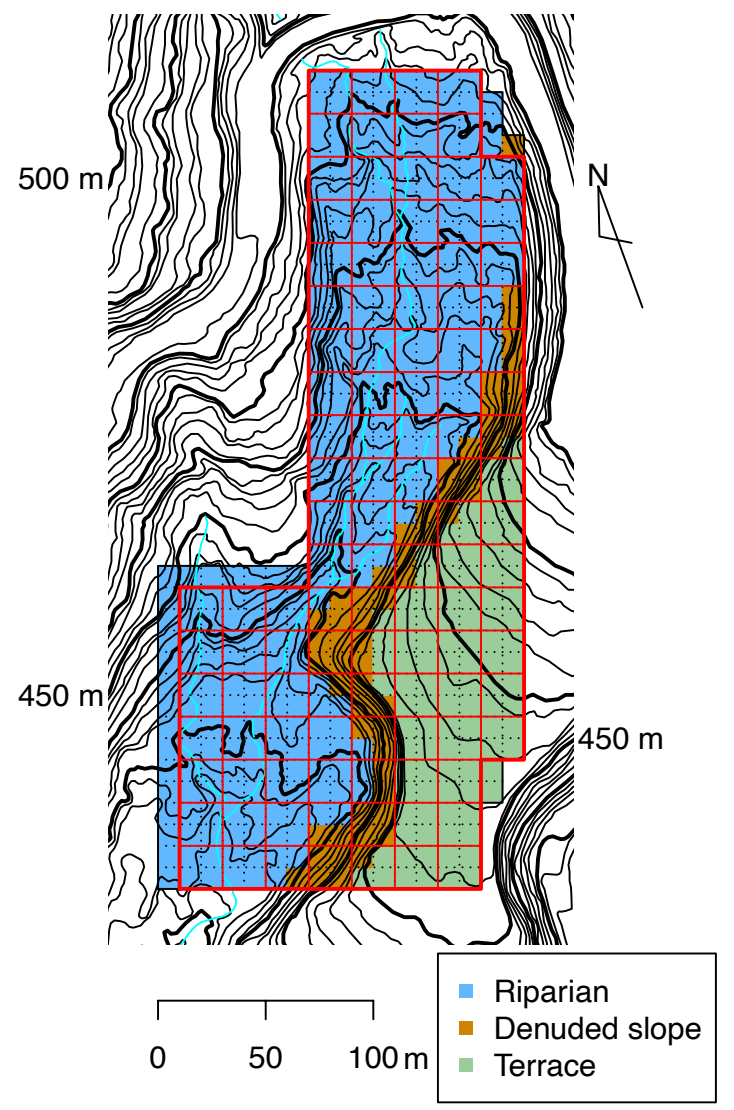


Fig. 2

(a) Riparian
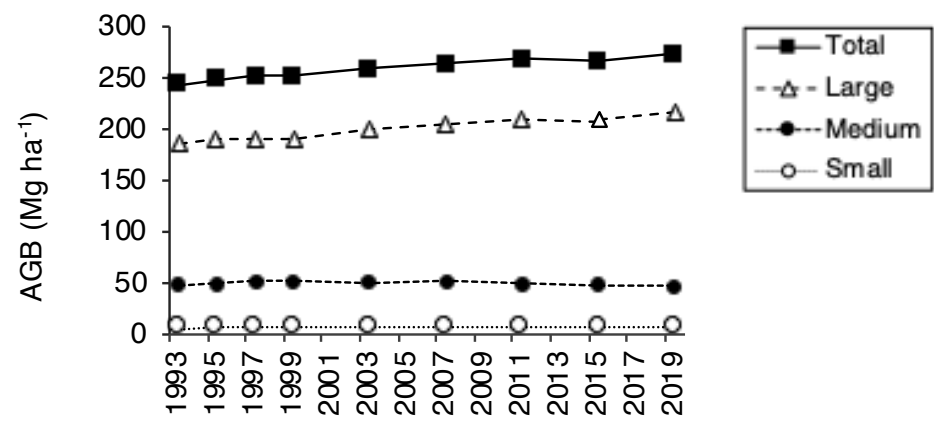

(b) Denuded slope

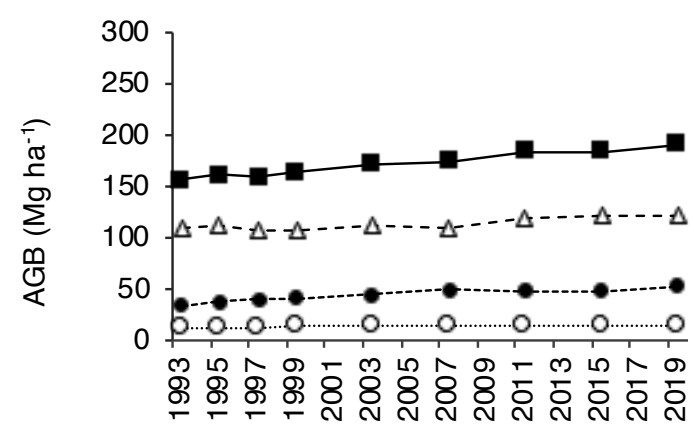

(c) Terrace

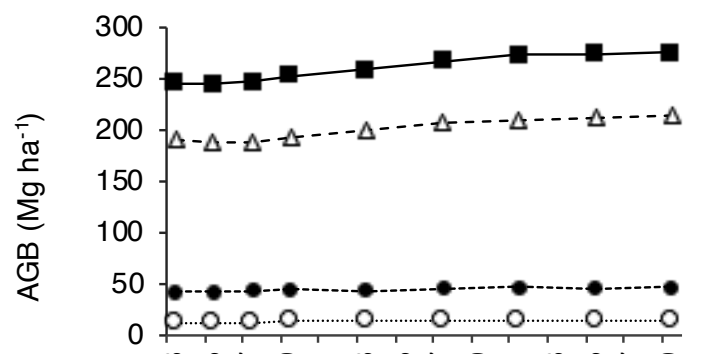

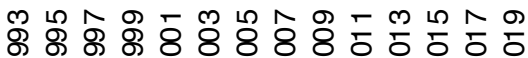

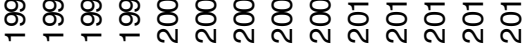


Fig. 3

(a) Riparian
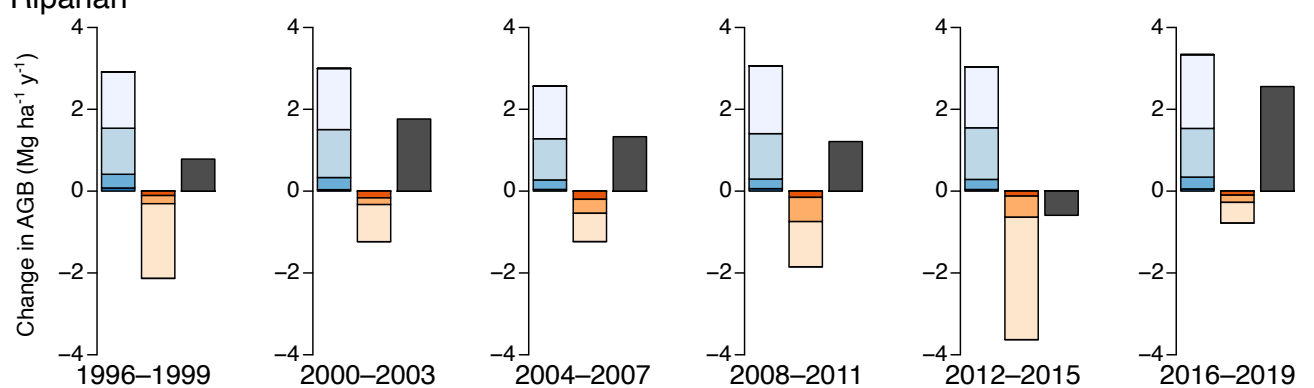

(b) Denuded Slope
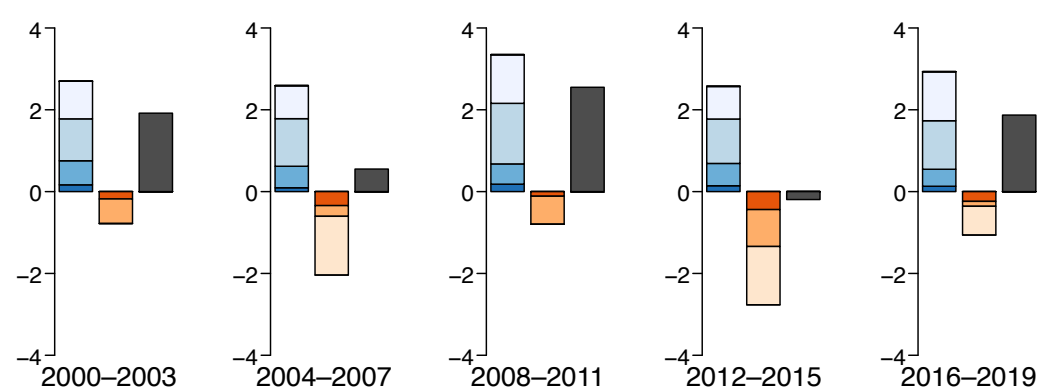

Annual gain in $A G B$ Growth $\square$ Large Small Ingrowth

Annual loss in AGB Mortality $\square$ Large $\square$ Small

(c) Terrace
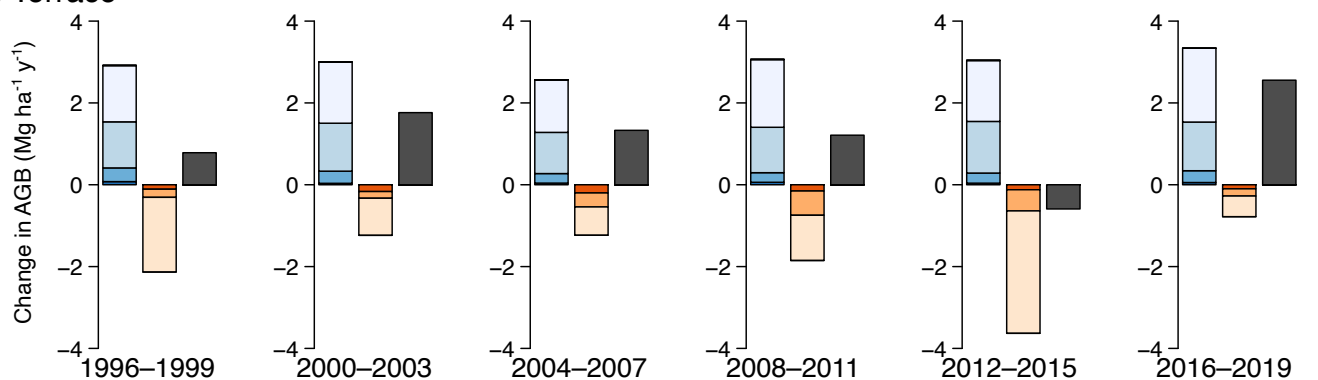

- Net annual change in AGB 
bioRxiv preprint doi: https://doi.org/10.1101/2021.07.02.450668; this version posted July 2, 2021. The copyright holder for this preprint (which was not certified by peer review) is the author/funder. All rights reserved. No reuse allowed without permission.

Fig.4

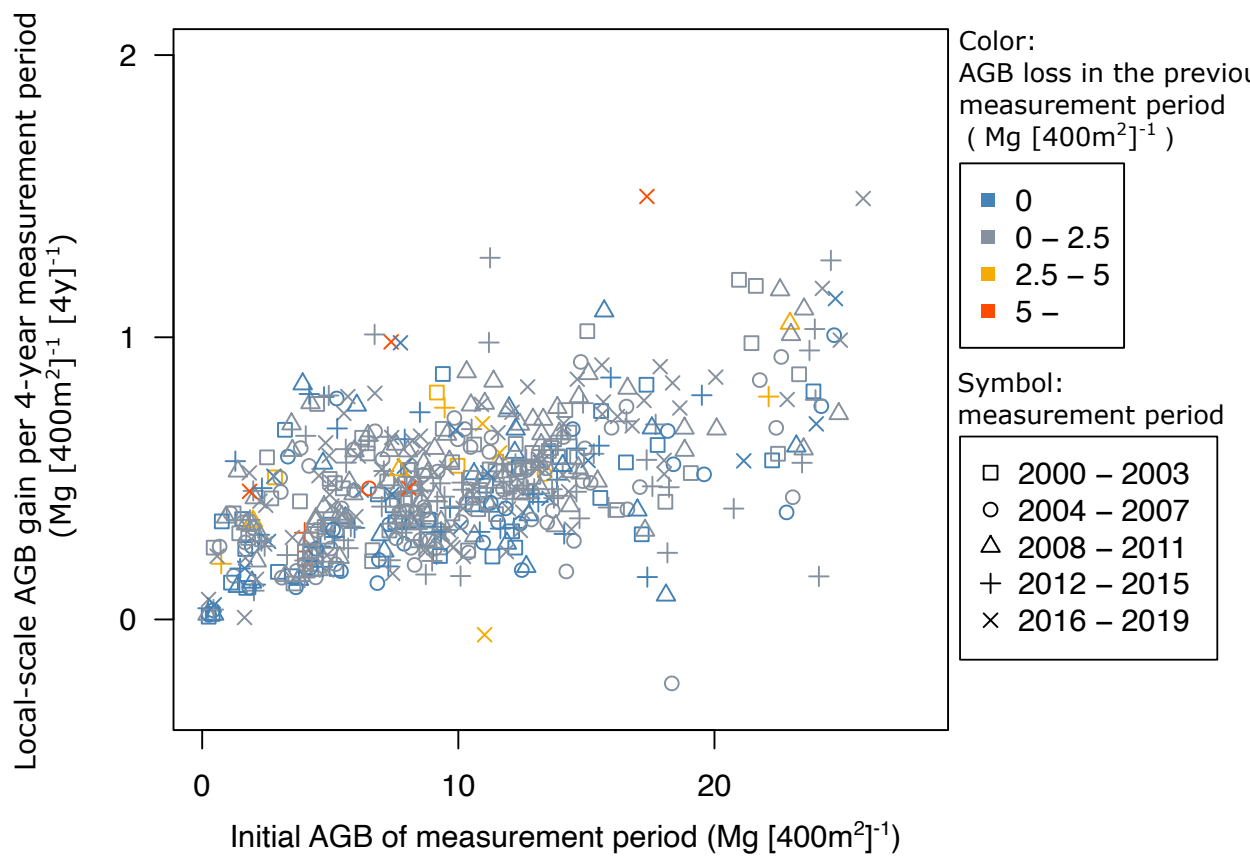

